\title{
Performance analysis of cooperative sugar factories in north-eastern Karnataka
}

\section{Yasmeen*}

Department of Agricultural Economics, College of Agriculture, University of Agricultural Sciences, Raichur (Karnataka), India

\section{Suresh S. Patil}

Department of Agricultural Economics, College of Agriculture, B'Gudi, University of Agricultural Sciences, Raichur (Karnataka), India

\section{G. M. Hiremath}

Department of Agricultural Economics, College of Agriculture, University of Agricultural Sciences, Raichur, (Karnataka) India

\section{B. S. Reddy}

Department of Agricultural Economics, College of Agriculture, Kalaburagi, University of Agricultural Sciences, Raichur (Karnataka), India

*Corresponding author. E-mail: itsmeyas786@gmail.com

\section{Abstract}

The study was attempted to measure the economic performance of cooperative sugar factories in terms of total costs and returns, capacity utilization, physical and financial indicators and ratio analysis of the factories. In this study the three cooperative sugar factories are taken into consideration and the Compound Annual Growth Rate (CAGR) for all the physical and financial indicators are worked out wherein the results suggested that a significant variation in the total cost and returns, capacity utilization and both physical and financial indicators over years within the three sugar factories was found. Further, the study revealed enough evidence about the financial ratios, which in turn showed the economic potentiality of the respective sugar factories. For the better performance of the factories an efficient planning and automation well before the start of the season is necessary and the government should come forward to help the farmers in making the cane bill payment at an early stage by the factories, by extending the financial assistance.

Keywords: CAGR, Physical and financial indicators, Performance, Ratio analysis

\section{Article Info}

DOI:10.31018/jans.v10i2.1676

Received: February 23, 2018

Revised: April 17, 2018

Accepted: May 11, 2018

\section{How to Cite}

Yasmeen, et al. (2018). Performance analysis of cooperative sugar factories in north-eastern Karnataka. Journal of Applied and Natural Science, 10(2): $741-745$

\section{INTRODUCTION}

Karnataka state is one among the major sugarcane and sugar-producing states in the country, as the sugarcane is being cultivated in large areas since many decades for manufacture of jaggery, khandsari and white sugar. It is also a major provider of livelihood to millions of agricultural families and their dependents particularly in rural areas (Nadoni et al. 2013). It has tremendous potential for increasing the cane cultivation and achieving higher yields, as the soil and climatic conditions are most suitable for planting the cane in different seasons (Jayaraja and Joh, 2012). It has conducive agro-climatic conditions for sugarcane cultivation resulting in increased sugarcane production year after year with the annual growth rate of 6.3 per cent which was significant at 5 per cent respectively, giving scope for establishment of more sugar units in the state. In Karnataka, sugarcane is produced to the tune of 35.73 million tonnes in an area of 0.43 million hectares. On an average, the productivity of the cane is 65 tonnes per ha. (Anonymous, 2013)

Karnataka is the second state in the country to establish a sugar factory. Mysore Sugar Company Ltd., Mandya, is the first sugar factory established in the year 1933-34 in public sector. Similarly, India Sugars and Refineries Ltd., Hospet, Bellary District in the private sector was established in 1934-35 (Sarbapriya, 2012). The Kampli Cooperative Sugar Factory Ltd., Kampli in Bellary District (now privatized and called M/S. Sundari Sugars Ltd.) in the cooperative sector was established in the year 1958-59. Over the past four decades, there is substantial rise in cane production in Karnataka. On account of this large number of sugar factories have come up (Girish , 2012). In the year 2014, 29 factories are operating in private and public sector and 20 under cooperative sector. Many sugar units in the state have also increased their installed crushing capacities. The annual crushing capacity is 250 lakh tonnes. In addition, byproducts like ethanol, co-generation 
and compost making have become integral part of sugar economy (Richard, 2014).

Bidar district is one of the major sugarcane and sugar producers of Karnataka state. The district has three cooperative sugar factories. The average crushing of all these sugar factories put together is around 18 lakh tonnes for the past three years. The three major cooperative sugar factories of the district are:1). Bidar Sahakari Sakkare Karkhane, Bidar (BSSK Ltd.) Estd-1970-71,2). Naranja Sahakari Sakkare Karkhane, Bidar (NSSK Ltd.) Estd-2001-02 , 3). Mahatma Gandhi Sahakari Sakkare Karkhane, Bidar (MGSSK Ltd.) Estd-2003-04.

Keeping all the above said points in view, the present study was carried to workout the economics of sugar production and the performance of cooperative sugar factories in North-eastern Karnataka.

\section{MATERIALS AND METHODS}

In North-eastern Karnataka (NEK) region, Bidar is one of the sugarcane producing area wherein sugar factories have been established in cooperative sectors and also khandsari in private sector. During the year 2005 khandsari have been closed due to their poor performance. Hence in the present study the factories which have been established are taken to study their growth and performance of all the following three sugar factories. The secondary data were collected from the published Annual reports maintained by the Bidar
Sahakara Sakkare Karkhane (BSSK), Naranja Sahakara Sakkare Karkhane (NSSK) and Mahatma Gandhi Sahakara Sakkare Karkhane (MGSSK) Ltd.

There is a variation in the study period for different factories due to the variation in the year of establishment. For instance, BSSK though it was established in 1970-71, the data is available from 199394 and hence data were collected for the period of 21 years. In the other two factories data were collected since their inspection i.e., NSSK from 200102 for the period of 13 years and MGSSK from 2003-04 for the period of 11 years respectively.

In aggregate, 24 performance indicators were identified to have close association with the functioning of the factories, of them nine indicators are related to physical aspects and they were termed as physical indicators, while the remaining 15 indicators related to the financial aspects of the factories and were termed as financial indicators.

\section{RESULTS AND DISCUSSION}

Cost and returns from sugar production: The relevant data relating to cost and returns from sugar production of all the three factories is presented in Table 1. The total cost of sugar production per quintal showed varying trend over the study period. The average cost of production per quintal of sugar in MGSSK was ` 802 . Whereas, in case of NSSK and BSSK it was' 820 and ' 671 respectively. The price of by-product of all the three sugar factories was studied. In all the three

Table 1. Cost and returns from sugar production in MGSSK, NSSK and BSSK Ltd., Bidar. (' Per quintal)

\begin{tabular}{|c|c|c|c|c|c|c|c|c|c|c|c|c|}
\hline \multirow{2}{*}{ Years } & \multicolumn{3}{|c|}{ Total costs } & \multicolumn{3}{|c|}{ By-products sales } & \multicolumn{3}{|c|}{ Price of sugar sales } & \multicolumn{3}{|c|}{ Total returns } \\
\hline & $\mathbf{M}$ & $\mathbf{N}$ & B & $M$ & $\mathbf{N}$ & B & $\mathbf{M}$ & $\mathbf{N}$ & B & $M$ & $\mathbf{N}$ & B \\
\hline 1993-94 & - & - & 237 & - & - & 21 & - & - & 745 & - & - & 672 \\
\hline $1994-95$ & - & - & 272 & _ & _ & 35 & _ & - & 796 & - & _ & 650 \\
\hline $1995-96$ & - & - & 306 & - & - & 46 & - & - & 800 & - & - & 701 \\
\hline $1996-97$ & _ & _ & 329 & _ & _ & 51 & _ & _ & 841 & _ & _ & 746 \\
\hline $1997-98$ & - & - & 337 & - & - & 66 & - & - & 910 & - & - & 800 \\
\hline $1998-99$ & - & - & 372 & - & - & 99 & - & - & 987 & - & - & 1200 \\
\hline 1999-00 & - & - & 395 & - & - & 105 & - & - & 1001 & - & - & 940 \\
\hline $2000-01$ & - & - & 415 & - & - & 115 & - & - & 1051 & - & - & 980 \\
\hline 2001-02 & - & 423 & 401 & - & 35 & 181 & - & 1246 & 1287 & - & 1282 & 1025 \\
\hline 2002-03 & - & 488 & 472 & - & 56 & 242 & - & 1377 & 1160 & - & 1433 & 1214 \\
\hline 2003-04 & 509 & 565 & 511 & 41 & 64 & 360 & 1052 & 1641 & 1269 & 1093 & 1705 & 1357 \\
\hline 2004-05 & 683 & 683 & 650 & 51 & 107 & 450 & 1123 & 1644 & 1456 & 1435 & 1751 & 1575 \\
\hline $2005-06$ & 537 & 611 & 617 & 91 & 191 & 476 & 1588 & 1538 & 1587 & 1694 & 1729 & 1635 \\
\hline 2006-07 & 471 & 706 & 661 & 122 & 352 & 581 & 2135 & 1236 & 1632 & 2544 & 1588 & 1941 \\
\hline 2007-08 & 654 & 792 & 754 & 183 & 448 & 610 & 3654 & 1547 & 2076 & 3960 & 1995 & 2404 \\
\hline 2008-09 & 1206 & 901 & 912 & 323 & 595 & 700 & 3105 & 1624 & 1966 & 3525 & 2219 & 3051 \\
\hline 2009-10 & 867 & 832 & 1087 & 547 & 671 & 750 & 2757 & 2063 & 2094 & 2964 & 2734 & 2963 \\
\hline $2010-11$ & 1010 & 965 & 1147 & 865 & 837 & 814 & 1865 & 1976 & 2396 & 2055 & 2813 & 3021 \\
\hline 2011-12 & 985 & 1073 & 1216 & 944 & 982 & 980 & 2199 & 2392 & 2548 & 2564 & 3374 & 3456 \\
\hline $2012-13$ & 1000 & 1201 & 1441 & 1095 & 1138 & 1051 & 2564 & 2306 & 2654 & 2985 & 3444 & 4014 \\
\hline 2013-14 & 901 & 1418 & 1565 & 1288 & 1280 & 1190 & 2986 & 2885 & 2980 & 3155 & 4165 & 4561 \\
\hline Average & 802 & 820 & 671 & 505 & 520 & 425 & 2275 & 1860 & 1535 & 2543 & 2326 & 1853 \\
\hline CAGR (\%) & $7.5^{* * *}$ & 9.3 & 9.5 & 25.8 & 26.5 & 22.1 & $8.4^{* *}$ & $5.9^{* \star \star \star}$ & 7.3 & $8.2^{* *}$ & 9.7 & $10.6^{*}$ \\
\hline
\end{tabular}

Note: - Data not available, M = MGSSK, N = NSSK and B = BSSK, ${ }^{* *}$ Significant at $1 \%$ level, ${ }^{* \star}$ Significant at $5 \%$ level 
Table 2. Total cane crushed, duration of cane crushed and capacity utilizationin MGSSK, NSSK and BSSK Ltd., Bidar.

\begin{tabular}{|c|c|c|c|c|c|c|c|c|c|c|c|c|}
\hline \multirow{2}{*}{ Years } & \multicolumn{3}{|c|}{ Total cane crushed (MT) } & \multicolumn{3}{|c|}{$\begin{array}{l}\text { Average duration } \\
\text { cane crushed (Days) }\end{array}$} & \multicolumn{3}{|c|}{$\begin{array}{l}\text { Daily capacity (MT I } \\
\text { day) }\end{array}$} & \multicolumn{3}{|c|}{$\begin{array}{l}\text { Capacity } \\
(\%)\end{array}$} \\
\hline & M & $\mathbf{N}$ & B & M & $\mathbf{N}$ & B & $M$ & $\mathbf{N}$ & B & $M$ & $\mathbf{N}$ & B \\
\hline 1993-94 & - & - & 249343 & - & - & 140 & - & - & 3500 & - & - & 50.9 \\
\hline $1994-95$ & - & - & 442616 & - & - & 190 & - & - & 3500 & - & - & 66.6 \\
\hline $1995-96$ & - & - & 297126 & - & - & 150 & - & - & 3500 & - & - & 56.6 \\
\hline $1996-97$ & - & - & 342258 & - & - & 144 & - & - & 3500 & - & - & 67.9 \\
\hline $1997-98$ & - & - & 403244 & - & - & 150 & - & - & 3500 & - & - & 76.8 \\
\hline 1998-99 & - & - & 450986 & - & - & 168 & - & - & 3500 & - & - & 76.7 \\
\hline $1999-00$ & - & - & 650002 & - & - & 198 & - & - & 3500 & - & - & 93.0 \\
\hline 2000-01 & - & - & 466393 & - & - & 163 & - & - & 3500 & - & - & 81.8 \\
\hline 2001-02 & - & 302105 & 415933 & - & 103 & 139 & - & 2500 & 3500 & - & 124.8 & 85.5 \\
\hline 2002-03 & - & 395991 & 446760 & - & 157 & 161 & - & 2500 & 3500 & - & 100.9 & 79.3 \\
\hline 2003-04 & 22548 & 270981 & 266347 & 40 & 93 & 87 & 2500 & 2500 & 3500 & 22.6 & 116.6 & 87.5 \\
\hline 2004-05 & 26703 & 108845 & 224253 & 53 & 69 & 92 & 2500 & 2500 & 3500 & 20.2 & 63.1 & 69.6 \\
\hline $2005-06$ & 156296 & 407004 & 320659 & 120 & 154 & 143 & 2500 & 2500 & 3500 & 52.1 & 105.7 & 64.1 \\
\hline 2006-07 & 393098 & 620042 & 653043 & 192 & 196 & 200 & 2500 & 2500 & 3500 & 81.9 & 126.5 & 93.8 \\
\hline 2007-08 & 275162 & 505275 & 430546 & 158 & 180 & 174 & 2500 & 2500 & 3500 & 69.7 & 111.8 & 70.7 \\
\hline 2008-09 & 168163 & 250607 & 197340 & 99 & 89 & 92 & 2500 & 2500 & 3500 & 67.9 & 112.2 & 61.3 \\
\hline $2009-10$ & 402220 & 430338 & 339779 & 166 & 157 & 126 & 2500 & 2500 & 3500 & 96.9 & 109.4 & 77.1 \\
\hline 2010-11 & 440558 & 478429 & 380855 & 167 & 169 & 143 & 2500 & 2500 & 3500 & 105.5 & 113.0 & 76.1 \\
\hline $2011-12$ & 453806 & 498374 & 447494 & 161 & 157 & 158 & 2500 & 2500 & 3500 & 112.8 & 126.8 & 80.9 \\
\hline $2012-13$ & 521472 & 517682 & 414670 & 152 & 153 & 144 & 2500 & 2500 & 3500 & 137.2 & 134.7 & 82.3 \\
\hline 2013-14 & 525685 & 500617 & 418558 & 164 & 156 & 154 & 2500 & 2500 & 3500 & 128.2 & 127.6 & 77.7 \\
\hline Average & 307792 & 408110 & 393248 & 133 & 141 & 148 & 2500 & 2500 & 3500 & 81.4 & 113.0 & 75.1 \\
\hline CAGR (\%) & $33.3^{*+* t}$ & $5.9^{*}$ & 0.2 & $11.4^{* * *}$ & $3.5^{*}$ & -0.7 & - & - & - & - & - & - \\
\hline
\end{tabular}

Note: Average recovery per cent for 100 tonnes of cane; Data not available, $\mathrm{M}=\mathrm{MGSSK}, \mathrm{N}=\mathrm{NSSK}$ and $\mathrm{B}=$ BSSK; Significant at $1 \%$ level, ${ }^{* *}$ Significant at $5 \%$ level, * Significant at $10 \%$ level

Table 3. Growth performance of physical indicators of cooperative sugar factories in Bidar district.

\begin{tabular}{|c|c|c|c|c|}
\hline SI. No. & Particulars & MGSSK & NSSK & BSSK \\
\hline 1 & Grower members & 11.1 & $-1.0^{*}$ & 3.7 \\
\hline 2 & Total members & 4.9 & $1.2^{\star \star}$ & 4.0 \\
\hline 3 & Sugarcane area under area of operation (Acres) & 8.1 & $4.0^{* * \star}$ & 7.7 \\
\hline 4 & Average yield (Tonne/ha) & $1.5^{* *}$ & $1.2^{\star \star \star}$ & 1.3 \\
\hline 5 & Cane bill per MT (’) & $12.3^{*}$ & 11.2 & $7.1^{* *}$ \\
\hline 6 & Average duration of the crushing season (Days) & $11.2^{* *}$ & $4.8^{*}$ & 6.8 \\
\hline 7 & Sugarcane crushed (MT) & $27.7^{\star \star}$ & $5.8^{*}$ & $2.2^{\star *}$ \\
\hline 8 & Sugar bagged (Quintals) & $30.1^{\star \star * *}$ & $8.5^{* *}$ & 6.8 \\
\hline 9 & Average sugar recovery & $0.8^{*}$ & $0.7^{* *}$ & $0.5^{\star *}$ \\
\hline
\end{tabular}

*** Significant at $1 \%$ level, ** Significant at $5 \%$ level, * Significant at $10 \%$ level

sugar factories the price has increased gradually. Whereas, the price of sugar also showed the increasing trend with the average of 2275 per quintal in MGSSK and ' 1860 and ` 1535 in NSSK and BSSK respectively. The average total returns of sugar over the study period was ' 2543 per quintal in MGSSK (10 years), whereas in NSSK (13 years) and BSSK (21 years) it was ` 2326 and 1853 respectively. The CAGR was worked out wherein, total cost $(7.5 \%)$ and returns $(8.2 \%)$ were significant at 1 and 5 per cent respectively. These results are in conformity with the study conducted by (Ravi, 2013) which revealed that, for the effective control of sugar industry the different cost components are very much responsible.

These factors implied that the sugarcane prices, other variable costs and fixed costs have increased both in absolute terms as well as in rela- tion to the total returns compared to other costs during the period under review.

Capacity utilization in sugar factories: The capacity utilization of MGSSK, NSSK and BSSK over the 10,13 and 21 years respectively is presented in Table 2. Sugarcane crushed fluctuated over the years, in MGSSK, NSSK and BSSK an average of $3,07,792,4,08,110$ and $3,93,247$ metric tonnes respectively. The average number of crushing days in MGSSK were 133, whereas in case of NSSK the average number of crushing days were 141 and 148 in BSSK respectively.

The capacity utilization by MGSSK showed varying trend over the study period. Average capacity utilization was 81.4 per cent over the study period with the average daily capacity of 2500 metric tonnes. In case of NSSK the average capacity utilization was 113.0 per cent with the average daily capacity of 2500 metric tonnes, and in BSSK the average 
Table 4. Growth performance of financial indicators of cooperative sugar factories in Bidar district.

\begin{tabular}{llll}
\hline Particulars & MGSSK & NSSK & BSSK \\
\hline Share capital & $0.3^{*}$ & 2.5 & 4.0 \\
Reserve fund and & $7.2^{*}$ & 1.1 & 8.7 \\
Surplus & 2.5 & 2.4 & 4.4 \\
Owned fund & 26.9 & $13.5^{* *}$ & 3.4 \\
Current assets & $7.1^{* *}$ & 2.6 & 2.0 \\
Fixed assets & 14.9 & 6.8 & 2.9 \\
Total assets & $21.2^{* * *}$ & 14.6 & 4.3 \\
Current liabilities & 19.8 & 5.4 & 3.3 \\
Total borrowings & 18.6 & 7.7 & 3.5 \\
Total liabilities & 36.4 & 18.5 & 7.7 \\
Total sales & $3.9^{* *}$ & $6.3^{* *}$ & $-3.0^{*}$ \\
Gross income & 31.2 & 7.5 & $12.5^{* *}$ \\
Total expenses & 31.5 & 28.0 & $14.4^{* *}$ \\
Inventory & $19.0^{* * *}$ & 20.9 & 3.5 \\
Depreciation &
\end{tabular}

***Significant at $1 \%$ level, ${ }^{* *}$ Significant at $5 \%$ level,

* Significant at $10 \%$ level

capacity utilization was 75.1 per cent with average daily capacity of 3500 metric tonnes over the study period. The CAGR was worked out for total cane crushed wherein the significance was observed in MGSSK (33.3\%) and NSSK (5.9\%) respectively.

These results are in conformity with (Ravi, 2013) and (Sarbapriya, 2012) who concluded that the capacity utilization showed the significant variation with the better farming and harvesting practices.

Growth performance of physical indicators: The CAGR related to number of grower members, sugarcane cultivated area in the area of operation, sugarcane area under registered members, average yield, cane bill per metric tonnes, duration of the season, sugarcane crushed, sugar manufactured, sugar recovery per cent of MGSSK, NSSK and BSSK are presented in Table 3. The highest growth rate was recorded by sugar bagged (30.1\%) in MGSSK which was significant at 5 per cent level, followed by sugarcane crushed $(27.7 \%)$ and grower members (11.1\%). In case of NSSK the highest growth rate was recorded by cane bill per metric tonne $(11.2 \%)$, followed by sugar bagged $(8.5 \%)$ and average duration of the crushing season $(4.8 \%)$ respectively. In BSSK the highest growth rate was recorded by sugarcane area under area of operation $(7.7 \%)$ followed by cane bill per metric tonne $(7.1 \%)$ and sugar bagged $(6.8 \%)$ respectively. The increase in the growth of physical indicators was due to the increased sugarcane production and also recommendation of sugar rich variety against the long duration and also by providing incentives to the farmers for adopting the new varieties (Azad et al. 2011).

Growth performance of financial indicators: The CAGR on share capital, reserve funds, owned funds, fixed assets, total borrowings, current liabilities, total liabilities, total sales, gross income, total expenses, net profit/loss and depreciation of all the three factories are presented in Table 4. The highest growth rate in MGSSK was recorded by total sales $(36.4 \%)$ followed by inventory (31.5\%), total expenses $(31.2 \%)$ and total borrowings $(19.8 \%)$ respectively. Whereas in case of NSSK the highest growth rate was recorded by inventory $(28.0 \%)$ followed by depreciation $(20.9 \%)$ and surplus $(12.1 \%)$ respectively. In case of BSSK the highest growth rate was recorded by owned fund $(4.4 \%)$ followed by current liabilities $(4.3 \%)$, share capital $(4.0 \%)$ and reserve fund and surplus $(3.8 \%)$ respectively.

These results are in conformity with the findings of (Basheer, 2012), who reported that the growth of share capital of BSSK Itd was less than that of membership which implied that, the higher growth rate in share capital was due to higher contribution of individual members and the government.

Comparative statement of financial ratios: Table 5 provides the information regarding the aver-

Table 5. Comparative statement of financial ratios of cooperative sugar factories in Bidar district.

\begin{tabular}{|c|c|c|c|c|}
\hline \multirow{2}{*}{ Particulars } & \multirow{2}{*}{ Ratios } & \multicolumn{3}{|c|}{ Average ratios } \\
\hline & & MGSSK & NSSK & BSSK \\
\hline \multirow{3}{*}{ Tests of liquidity ratios } & Current ratio & 1.58 & 1.99 & 2.90 \\
\hline & Acid test ratio & 0.64 & 1.07 & 0.70 \\
\hline & Inventory ratio & 2.06 & 1.08 & 1.16 \\
\hline \multirow{3}{*}{ Tests of solvency ratios } & Total liabilities to owned funds ratio & 4.50 & 4.90 & 2.71 \\
\hline & Fixed assets to owned funds ratio & 2.65 & 3.14 & 1.06 \\
\hline & Debt equity ratio & 2.19 & 3.60 & 2.85 \\
\hline \multirow{3}{*}{ Tests of turnover ratios } & Inventory turnover ratio & 1.81 & 2.38 & 1.20 \\
\hline & Total assets turnover ratio & 0.52 & 0.44 & 0.55 \\
\hline & Working capital turnover ratio & 3.60 & 2.18 & 1.38 \\
\hline \multirow{3}{*}{$\begin{array}{l}\text { Tests of financial } \\
\text { strength }\end{array}$} & Networth ('in Lakhs) & 1719 & 2203 & 708 \\
\hline & Net capital ratio & 1.21 & 1.18 & 1.09 \\
\hline & Equity capital ratio & 0.60 & 0.87 & 0.34 \\
\hline \multirow{3}{*}{ Fixed assets ratios } & Fixed assets to total assets ratio & 0.55 & 0.56 & 0.36 \\
\hline & Fixed assets to net worth ratio & 3.77 & 4.26 & 5.70 \\
\hline & Fixed assets to total sales ratio & 1.64 & 1.70 & 0.70 \\
\hline \multirow{2}{*}{$\begin{array}{l}\text { Tests of efficiency and } \\
\text { profitability }\end{array}$} & Efficiency of capital ratio & 0.90 & 0.53 & 0.46 \\
\hline & Gross ratio & 1.26 & 2.20 & 1.62 \\
\hline
\end{tabular}


age financial ratios of MGSSK, NSSK and BSSK whereas in case of tests of liquidity ratios i.e., the current ratio was highest in BSSK, followed by acid test ratio in NSSK and inventory ratio in MGSSK, respectively. In case of tests of solvency all the three ratios were highest in NSSK the main reason behind this was reflection of financial strength of an organization to meet its medium and long term obligations, the margin of safety offered to the creditors and the potential earnings from the use of borrowed funds was perfectly recorded. Similarly in case of test of turnover, inventory turnover ratio was highest in NSSK, total assets turnover was recorded highest in NSSK and working capital ratio was highest in MGSSK respectively. In case of tests of efficiency and profitability, efficiency of capital ratio was recorded highest in MGSSK and gross ratio was highest in NSSK respectively. The higher ratio is associated with problem of liquidation, because the claims of the owners have to be met by sale of fixed assets, which are in non liquid form. A higher the efficiency of capital ratio indicated efficient utilization of capital (Page et al. 2000).

\section{Conclusion}

The performance of all the three sugar factories varied significantly due to difference in ownership, size and location of the factories. In order to utilize its capacity fully and run efficiently, the sugar factories within the industry should get uninterrupted supply of raw sugarcane uniformly throughout the seasons. There is a need of coordinated and concerted effort for appreciation and consolidation of the needs of the consumer, farmer and processor. There is an urgent need to improve in productivity both in terms of yield as well as sugar contents and recovery by adopting better harvesting practices and close coordination of sugar mills with farmers. It has been estimated that better farming and harvesting practices could result up to 1.0 per cent improvement in extraction which can lead to 10 per cent increase in production. Therefore, mills and farmers should work together to improve yield and extraction through better harvesting in order to become internationally competitive i.e., cost effective and quality producer.

\section{REFERENCES}

Anonymous (2013). Area, Production and Productivity of sugarcane. Retrieved from www.indiastat.com.

Azad, M. P., Yadav, R. N., Singh, M. and Kaushik, D. C. (2011), Comparative economic analysis of processing of sugar under public, co-operative and private sectors in Uttar Pradesh. Indian. J. Agric. Mktg., 4(1):55-59

Basheer Ahmad, (2012). Performance analysis of Bidar cooperative sugar factory limited, Bidar. Agri. Business. Management. Thesis, Univ. Agric. Sci., Bengaluru.

Girish, Nair (2012). An analysis on the financial performance and production efficiency of selected sugar mills in the state of Tamil Nadu, India. Ph. D. Thesis, Banasthali University, Rajasthan.

Jayaraja, Singh and Joh Samuel, J. (2012). A study on the Management of tiruttani co-operative sugar mills limited at Thiruvalangadu in Tiruvallur district. Int. $\mathrm{J}$. Mgt. Res. Rev., 2(6): 947-957.

Nadoni, N. N., Ananth, G. S., Dhananjaya Swamy and Manjunath. S. Kerur. (2013). Performance appraisal of co-operative and private sugar factory in Belgaum district - An economic analysis. Global J. Mgt. and Business Studies, 3(10): 1197-1207.

Page, R.E., Schermerhon, R.W. and Romine, B.D. (2000). Financial analysis of grain supply cooperatives in Oklohoma. Co-operative Extension Service, Oklohoma State University, Oklohoma, USA.

Ravi, Ambi (2013). Business performance of the Ugar Sugar Works Ltd, Athani. Agri. Business. Management. Thesis, Univ. Agric. Sci., Bengaluru.

Richard, A. (2014). Industrial development in Karnataka, Report, pp: 40-46.

Sarbapriya Ray, (2012) Reviewing performance of Indian sugar industry: an economic analysis. Food Sci. and Quality Mgt., 3: 35-53. 